\title{
Phylogenetic relationships of two Ukrainian tomato isolates of potato virus $M$ and genetic variability analysis of its population
}

\author{
L. MISHCHENKO ${ }^{1}$, A. DUNICH ${ }^{1}$, O. TARAN ${ }^{2}$, A. DASHCHENKO ${ }^{2}$, V. POLISCHUK 1 , O. KONDRATYUK ${ }^{1}$
}

\begin{abstract}
${ }^{1}$ Virology department, ESC "Institute of Biology and Medicine", Taras Shevchenko National University of Kyiv, Volodymyrska str. 64/13, Kyiv, 01601, Ukraine; ${ }^{2}$ National University of Life and Environmental Sciences of Ukraine, Heroyiv Oborony str. 15 , Kyiv, 03041, Ukraine
\end{abstract}

Received August 21, 2017; revised September 28, 2017; accepted April 27, 2018

\begin{abstract}
Summary. - The aim of this study was to investigate biological and molecular properties of two Ukrainian tomato isolates of potato virus M (PVM), K-16 and Pol-14, to determine their phylogenetic relationships and the genetic variability of PVM isolates. Study of phylogenetic relationships of two Ukrainian tomato PVM isolates with 35 isolates represented in GenBank was conducted. It was found that the coat protein $(\mathrm{CP})$ gene sequence identity between two Ukrainian PVM isolates is $94.3 \%$ at the nucleotide level and $100 \%$ at the amino acid level. The highest level of the sequence identity ( $97.0 \%$ and $96.5 \%$ nt and $100 \%$ aa) have the isolates K-16 and Pol-14 with the German potato isolate DSMZ PV0273, Indian potato isolates Del 123, Del 134, Del 147, M 34 and Chinese isolate from pepino GS-6-2 (isolate K-16), which testifies about their common origin. Ukrainian tomato isolates K-16 and Pol-14 belong together with all European, Chinese, Iranian, Indian isolates to PVM-o clade or group I. It was found that the nucleotide substitutions in the capsid protein gene of all tomato PVM isolates (except the Italian) are synonymous. Analysis showed that the global $\mathrm{dN} / \mathrm{dS}$ ratio for the entire $\mathrm{CP}$ gene sequences used in the study was $0.041(\mathrm{p}<0.01)$. Pairwise comparisons showed that the $\mathrm{dN} / \mathrm{dS}$ values were also significantly lower than 1 for all of CP sequence pairs that testifies that the PVM CP gene experiences a negative (purifying) selection pressure.
\end{abstract}

Keywords: potato virus M; Solanum lycopersicum; phylogenetic analysis; genetic variability; selection pressure

\section{Introduction}

Development of modern approaches based on genome sequencing provides an opportunity to investigate the nucleotide sequences of the genomes of plant viruses and mathematically reliably establish degree of their relationship, making conclusions about their evolution (Garcia-Arenal et al., 2003). Due to high rates of replication and mutation, and large populations, RNA viruses have an abundant genetic variability in their natural populations (Lauring et al., 2013). Knowledge of the population structure of viruses

E-mail: tarasuniv@gmail.com; phone: +38 044 258-32-40.

Abbreviations: $\mathrm{CP}=$ coat protein; $\mathrm{PLRV}=$ potato leafroll virus; $\mathrm{PVM}=$ potato virus $\mathrm{M} ; \mathrm{PVS}=$ potato virus $\mathrm{S} ; \mathrm{PVX}=$ potato virus $\mathrm{X} ; \mathrm{PVY}=$ potato virus $\mathrm{Y} ; \mathrm{TMV}=$ tobacco mosaic virus will help us to understand such important features of their biology as changes in geographical range, phylogenetic relationships, epidemiological routes, the underlying evolutionary mechanisms of RNA viruses, and their emergence as new epidemics (Ge et al., 2014); this understanding will be essential for designing strategies for controlling viruses (Acosta-Leal et al., 2011).

The demarcation criteria for species delineation in the genus Carlavirus includes serological relatedness, host range and sequence identity of the $\mathrm{CP}$ gene (Adams and Antoniw, 2004; Mahy and Van Regenmortel, 2010). Sequence analysis has shown that members of distinct species of carlaviruses share less than $72 \%$ nucleotide sequence identity (or $80 \%$ amino acid sequence identity) in their entire CP genes. Currently, no reliable criteria have been specified for strain differentiation within a single carlavirus 
species; however, it has been suggested that different strains belonging to the same carlavirus species share $75-90 \%$ identity in the core region of their CPs (excluding the $\mathrm{N}$ and C termini) (Adams and Antoniw, 2004; Mahy and Van Regenmortel, 2010). So far, the population dynamics of carlaviruses has not been studied extensively. Different isolates of potato virus S (PVS), which is closely related to PVM, have been classified into two biologically different strains. Interestingly, it was found that this differentiation is reproducible by phylogenetic analysis of the PVS CP gene (Cox and Jones, 2010; Xu et al., 2010; Salari et al., 2011; Tabasinejad et al., 2014). This finding confirmed that the $\mathrm{CP}$ region is a suitable genomic region to study the genetic diversity of carlaviruses.

Recent studies of PVM genetic diversity showed that PVM isolates divided into two groups: group I, Euro-Asian, which includes tomato and potato isolates from Italy, Germany, Czech Republic, Latvia, China, India, Iran, Poland and Russia and group II (potato isolates from the USA and Canada) (Xu et al., 2010). Later, Tabasinejad et al. (2014) named these two major clades PVM-ordinary (PVM-o) and PVM-divergent (PVM-d), respectively. It was shown that potato isolates of PVM from Iran and Czech Republic are located within both clades (Tabasinejad et al., 2014; Plchova et al., 2015). This suggests that the geographical origin is not the only determining factor of the phylogenetic divergence of PVM isolates into two main clades. It should be noted that these studies are devoted to phylogenetic study of potato strains of PVM. Phylogenetic analysis of tomato PVM isolates was conducted only in China (Ge et al., 2012). The aim of this study was to investigate phylogenetic relationships of two Ukrainian tomato PVM isolates, establish their possible origin and genetic diversity of PVM isolates.

\section{Materials and Methods}

Samples collection and virus diagnostics. Tomato leaf samples with abaxial rolling symptoms were collected during 2014-2016 from the fields of Poltava and Kyiv regions in Ukraine.

Identification of the viruses in sap of tomato leaves was performed by DAS-ELISA. Specific antibodies against potato virus $\mathrm{M}$, potato virus $\mathrm{Y}$ (PVY), potato virus $\mathrm{S}$, potato virus X (PVX), potato leafroll virus (PLRV), and tobacco mosaic virus (TMV) (Loewe, Germany) were used. Antigen samples were prepared by grinding of leaf tissue in PBS buffer, $\mathrm{pH}$ 7.4, at the ratio 1:2 (w/V). Leaf samples from healthy tomatoes were also included as negative controls. Positive controls were commercial (Loewe, Germany). The results were recorded on Termo Labsystems Opsis MR reader (USA) with Dynex Revelation Quicklink software at the wavelength of $405 \mathrm{~nm}$. Samples were considered positive when their absorbance values at $405 \mathrm{~nm}$ were at least three times higher than those of negative controls (Crowther, 1995).
Viral particle morphology was studied by transmission electron microscopy. Negative staining of virions was performed with the $2 \%$ solution of phosphotungstic acid for 2 minutes and studied by electron microscope JEM 1400 (JEOL, Japan).

Molecular analyses. Total RNA was extracted from fresh leaves using Genomic DNA purification kit (Thermo Scientific, USA) following the manufacturer's instructions. Two step RT-PCR was performed. The reverse transcription was performed using RevertAid Reverse Transcriptase - genetically modified Moloney murine leukemia virus reverse transcriptase, MMuLV RT (Thermo Scientific, USA) according to the manufacturer's instructions. Amplification was performed using thermocycler (Genetic research instrumentation LTD, Great Britain). Specific oligonucleotide primers to part of PVM CP gene were used: PVM1 (5' taactgcagatgccgtcttg 3'), PVM2 (5' tgcgatgtcttgt gcgtat 3') (Antipov et al., 2007). DNA product of 276 bp was amplified. Amplification was performed in 12,5 $\mu$ l of Dream Taq PCR Master Mix (2x) buffer (containing Dream Taq DNA polymerase, $2 \mathrm{x}$ Dream Taq buffer, $0,4 \mathrm{mmol} / \mathrm{l}$ of each dNTP and $4 \mathrm{mmol} / \mathrm{l}$ of $\left.\mathrm{MgCl}_{2}\right), 7,5 \mu \mathrm{l}$ nuclease-free water, $1 \mu \mathrm{l}$ of each primer $(10 \mu \mathrm{mol} / \mathrm{l})$, and $3 \mu \mathrm{l}$ of cDNA. The temperature regime for amplification reactions was as follows: initial denaturation for $3 \mathrm{~min}$ at $95^{\circ} \mathrm{C}$, followed by 35 cycles of $95^{\circ} \mathrm{C}$ for $30 \mathrm{~s}, 60^{\circ} \mathrm{C}$ for $30 \mathrm{~s}$, and $72^{\circ} \mathrm{C}$ for $30 \mathrm{~s}$. The final extension was at $72^{\circ} \mathrm{C}$ for $10 \mathrm{~min}$. PCR products were separated on a $1.5 \%$ agarose gel with DNA marker MassRuler DNA Ladder Mix ready-to-use (SM 0403, Thermo Scientific, USA), stained with ethidium bromide, and visualized under UV light. The PCR products were purified from the agarose gel using a QIAquick Gel Extraction Kit (Qiagen, Great Britain). Sequencing of the purified amplified DNA fragments was carried out with the 3130 Genetic Analyzer (Applied Biosystems, USA).

Phylogenetic analysis. Sequences of Ukrainian PVM isolates were compared with PVM sequences in the NCBI database with the BLAST program (http:// www.ncbi.nlm.him.gov). PVM isolates used in this study are listed in Table 1. Nucleotide and amino acid sequences were aligned using Clustal W in MEGA 7 (http://www. megasoftware.net/). Phylogenetic trees for the part of coat protein gene of 2 Ukrainian PVM isolates and 35 PVM isolates from different countries were constructed by the maximum-likelihood method (ML) (Huelsenbeck and Rannala, 1997) using the bestfitting models. To check the reliability of the constructed tree we used bootstrap test with 1000 bootstrap replications. Multiple alignment of the coat protein amino acid sequences of PVM isolates was performed by EBI CLUSTALW (2.1) (http://www.ebi.ac.uk/ Tools/msa/clustalw2/).

Synonymous/nonsynonymous (dN/dS) mutation ratio calculations. To calculate the $\mathrm{dN} / \mathrm{dS}$ ratio, an indicator of the evolutionary direction, the CP nucleotide sequences of all PVM isolates were codon-aligned. The ratio of the rate of nonsynonymous $(\mathrm{dN})$ to the rate of synonymous (dS) mutations was calculated using the Nei-Gojoboori method in the SNAP program (http://www.hiv.lanl. gov/content/ sequence/SNAP/SNAP.html). 


\section{Results and Discussion}

A survey of tomato plants (Solanum lycopersicum) in fields in Kyiv and Poltava regions of Ukraine showed that 18 to $25 \%$ of the inspected plants demonstrated abaxial leaf rolling (Fig. 1). Plant samples with such symptoms were taken to the study. It should be noted that tomato isolates of PVM from China caused mosaics on the tomato leaves and latent infection (Ge et al., 2012) but didn't induce abaxial leaf rolling like in Ukraine. Italian PVM-To isolate in mixed infection with PVY induced severe stunting accompanied by rolling and distortion of the leaflets, whereas infection by PVM-To alone was symptomless (Grieco et al., 1997). Previously, we have found that abaxial leaf rolling symptoms on tomato in Ukraine are caused by PVM or PVY or co-infection of both viruses (Mishchenko et al., 2013).

Therefore, ELISA was performed with antibodies against PVM and PVY. Antibodies against PVS, PVX and PLRV were also used. DAS-ELISA and RT-PCR showed that all tomato samples with abaxial leafrolling symptoms selected in 2014 were infected with PVM (61/152; infected/total) or PVM+PVY (91/152). In contrast, in 2016 only PVM was detected in tomato samples with abaxial leafrolling symptoms (24/24). PVY, PVS, PVX and PLRV antigens were not detected. One sample (cv. Hurma, Kyiv region, 2016) was PVM+TMV positive. It should be noted that during our long-term studies of the nature of abaxial leaf rolling symptoms on tomatoes in Ukraine (over 10 years) this is the first detection of TMV in co-infection with PVM or PVY. Two PVM-positive samples were taken for this study: tomato plants cv. Hurma, Kyiv region, 2016 and cv. Mir, Poltava region, 2014. PVM isolates from these plant samples were named K-16 and Pol-14, respectively.

To study the morphological features of tomato PVM isolates, transmission electron microscopy method was used. It was found that virions of tomato PVM isolates K-16 and Pol-14 are filamentous, $630 \pm 20 \times 13 \mathrm{~nm}$ in size. Thus, the size and morphology of virions of Ukrainian tomato PVM isolates K-16 and Pol-14 are typical for carlaviruses and do not differ from other potato and tomato PVM isolates described in the literature (Grieco et al., 1997; Adams et al., 2012; Mishchenko et al., 2013).

To investigate phylogenetic relationships of two Ukrainian tomato PVM isolates K-16 and Pol-14, DNA sequences were compared with the sequences of 35 PVM isolates and strains from GenBank (Table 1). Phylogenetic analysis of the nucleotide sequences of the part (211 nt) of CP gene (positions 7822-8032 nt) of PVM isolates K-16 and Pol-14 and 35 isolates and strains of this virus showed the highest level of the pairwise sequence identity with a number of European, Indian, Iranian and Chinese PVM isolates (Table 1). The sequence identity between two Ukrainian PVM isolates was 94.3\% at the nucleotide level and $100 \%$ at the amino acid level.

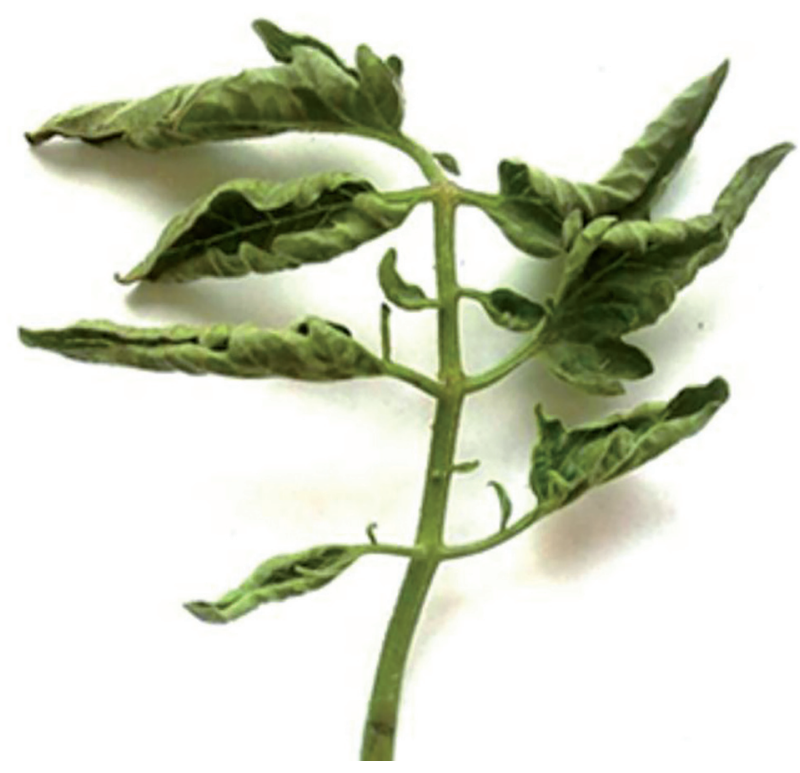

Fig. 1

Abaxial leaf rolling on tomato caused by PVM

The highest level of the nucleotide sequence identity (97.0\% and 96.5\%) and amino acid sequence (100\%) had isolates K-16 and Pol-14 with the German potato isolate DSMZ PV0273 and Indian potato isolates Del 123, Del 134, Del 147 and M 34, which testifies about their common origin (Fig. 2). It should be noted that isolate K-16 had also the highest percentage of homology (97.0\% nt and $100 \% \mathrm{aa})$ for nucleotide and amino acid sequence, respectively, with Chinese isolate from pepino GS-6-2 (Table 1). According to the two classifications of PVM strains proposed by Tabasinejad et al. (2014) and $\mathrm{Xu}$ et al. (2010), Ukrainian tomato isolates K-16 and Pol-14 with all European, Chinese, Iranian, Indian isolates belong to PVM-o clade or group I, respectively (Fig. 2). Canadian isolates formed a second clade (PVM-d or group II) and had a low percentage of nucleotide sequence homology with studied isolate K-16 (70.0-72.1\%) and Pol14 (70.7-73.6\%) (Fig. 2, Table 1). Such indicators are lower than the demarcation threshold for species differentiation (Adams and Antoniw, 2004; Mahy and Van Regenmortel, 2010), which testifies about the high variability of PVM population. Similar data was obtained by Tabasinejad et al., their result was $73.3 \%$, as a conclusion they stated: "high intrapopulation diversity of PVM CP suggests the involvement of mechanisms other than just point mutations and may have resulted from differential host or vector selection pressure" (Tabasinejad et al., 2014).

Results about possible origin of Ukrainian PVM isolates coincide with historical facts about the import of potatoes to Ukraine. According to these data, potato was 
Table 1. Nucleotide and amino acid sequence identity of part of the CP gene of the Ukrainian tomato PVM isolates with isolates/strains from other countries (\%)

\begin{tabular}{|c|c|c|c|c|c|c|c|c|c|}
\hline \multirow{2}{*}{ No. } & \multirow{2}{*}{$\begin{array}{l}\text { Isolate/strain } \\
\text { name }\end{array}$} & \multirow{2}{*}{$\begin{array}{l}\text { Acc. No. in } \\
\text { GenBank }\end{array}$} & \multicolumn{2}{|c|}{ K-16 } & \multicolumn{2}{|c|}{ Pol-14 } & \multirow{2}{*}{$\begin{array}{l}\text { Country of } \\
\text { origin }\end{array}$} & \multirow{2}{*}{ Host } & \multirow{2}{*}{ Reference } \\
\hline & & & nt & aa & nt & aa & & & \\
\hline 1 & $\mathrm{~K}-16$ & MF998090 & --- & --- & 94.3 & 100 & Ukraine & Solanum lycopersicum & This study \\
\hline 2 & Pol-14 & MF998089 & 94.3 & 100 & --- & --- & Ukraine & Solanum lycopersicum & This study \\
\hline 3. & GS-T1 & KF561661 & 93.8 & 100 & 92.2 & 100 & China & Solanum lycopersicum & Ge et al., 2014 \\
\hline 4. & GS-T8 & KF561662 & 93.8 & 100 & 92.2 & 100 & China & Solanum lycopersicum & Ge et al., 2014 \\
\hline 5. & GS-T10 & KF561663 & 93.8 & 100 & 92.2 & 100 & China & Solanum lycopersicum & Ge et al., 2014 \\
\hline 6. & Gansu & JN835299 & 93.8 & 100 & 92.2 & 100 & China & Solanum lycopersicum & Ge et al., 2012 \\
\hline 7. & Bari & X85114 & 95.4 & 98.4 & 94.9 & 98.4 & Italy & Solanum lycopersicum & Grieco et al., 1997 \\
\hline 8. & JL-3-9 & KF561612 & 95.4 & 100 & 93.8 & 100 & China & Solanum muricatum & Ge et al., 2014 \\
\hline 9. & YN-1-7 & KF561667 & 96.5 & 100 & 94.9 & 100 & China & Solanum muricatum & Ge et al., 2014 \\
\hline 10. & YN-2-6 & KF561647 & 96.5 & 100 & 94.9 & 100 & China & Solanum muricatum & Ge et al., 2014 \\
\hline 11. & YN-1-8 & KF561645 & 96.5 & 100 & 94.9 & 100 & China & Solanum muricatum & Ge et al., 2014 \\
\hline 12 & YN-1-1 & KF561642 & 96.5 & 100 & 94.9 & 100 & China & Solanum muricatum & Ge et al., 2014 \\
\hline 13 & GS-6-2 & KF561638 & 97.0 & 100 & 93.8 & 100 & China & Solanum muricatum & Ge et al., 2014 \\
\hline 14 & AGF-5 & KJ919964 & 96.5 & 100 & 96.5 & 100 & India & Solanum tuberosum & GeneBank \\
\hline 15 & Del-147 & KJ462137 & 97.0 & 100 & 96.5 & 100 & India & Solanum tuberosum & GeneBank \\
\hline 16 & Del-134 & KJ462136 & 97.0 & 100 & 96.5 & 100 & India & Solanum tuberosum & GeneBank \\
\hline 17 & Del-123 & KJ462135 & 97.0 & 100 & 96.5 & 100 & India & Solanum tuberosum & GeneBank \\
\hline 18 & M-34 & KF471070 & 97.0 & 100 & 96.5 & 100 & India & Solanum tuberosum & Katiyar et al., 2013 \\
\hline 19 & Russian wild & D14449 & 95.4 & 98.4 & 94.9 & 98.4 & Russia & Solanum tuberosum & Zavriev et al., 1991 \\
\hline 20 & Ar-17 & EF397744 & 94.3 & 96.8 & 93.8 & 96.8 & Iran & Solanum tuberosum & $\begin{array}{l}\text { Pourrahim et al., } \\
2007\end{array}$ \\
\hline 21 & Kh-92 & EF397743 & 94.3 & 96.8 & 93.8 & 96.8 & Iran & Solanum tuberosum & $\begin{array}{l}\text { Pourrahim et al., } \\
2007\end{array}$ \\
\hline 22 & На-64 & EF397747 & 94.9 & 98.4 & 94.3 & 98.4 & Iran & Solanum tuberosum & $\begin{array}{l}\text { Pourrahim et al., } \\
2007\end{array}$ \\
\hline 23 & Es-34 & EF397746 & 94.9 & 96.8 & 94.3 & 96.8 & Iran & Solanum tuberosum & $\begin{array}{l}\text { Pourrahim et al., } \\
2007\end{array}$ \\
\hline 24 & TZ:PVM12U:11 & KC866622 & 96.5 & 100 & 95.9 & 100 & Tanzania & Solanum tuberosum & Chiunga et al., 2013 \\
\hline 25 & DSMZ PV0273 & EU604672 & 97.0 & 100 & 96.5 & 100 & Germany & Solanum tuberosum & Flatken et al., 2008 \\
\hline 26 & Chernigov-05 & DQ883806 & 94.9 & 100 & 94.9 & 100 & Ukraine & Solanum tuberosum & Antipov et al., 2007 \\
\hline 27 & Priekuli & GQ496609 & 96.5 & 100 & 95.9 & 100 & Latvia & Solanum tuberosum & GeneBank \\
\hline 28 & VIRUBRA 4/007 & HM854296 & 95.4 & 98.4 & 94.9 & 98.4 & Czech Republic & Solanum tuberosum & Plchova et al., 2015 \\
\hline 29 & VIRUBRA 4/035 & HQ005276 & 94.3 & 98.4 & 94.9 & 98.4 & Czech Republic & Solanum tuberosum & Plchova et al., 2015 \\
\hline 30 & VIRUBRA 4/016 & HM991708 & 94.9 & 100 & 94.3 & 100 & Czech Republic & Solanum tuberosum & Plchova et al., 2015 \\
\hline 31 & M57 & AY311395 & 95.9 & 100 & 94.3 & 100 & Poland & Solanum tuberosum & GeneBank \\
\hline 32 & Uran & AY311394 & 95.9 & 100 & 94.3 & 100 & Poland & Solanum tuberosum & GeneBank \\
\hline 33 & Ca128 & EF063387 & 71.4 & 95.2 & 72.9 & 95.2 & Canada & Solanum tuberosum & Xu et al., 2010 \\
\hline 34 & CL4 & EF063385 & 71.4 & 95.2 & 72.9 & 95.2 & Canada & Solanum tuberosum & Xu et al., 2010 \\
\hline 35 & Ca513 & EF063389 & 70.0 & 87.1 & 70.7 & 87.1 & Canada & Solanum tuberosum & Xu et al., 2010 \\
\hline 36 & CL3 & EF063384 & 72.1 & 93.5 & 73.6 & 93.5 & Canada & Solanum tuberosum & Xu et al., 2010 \\
\hline 37 & $\mathrm{Ca} 508$ & EF063388 & 72.1 & 95.2 & 73.6 & 95.2 & Canada & Solanum tuberosum & Xu et al., 2010 \\
\hline
\end{tabular}

brought to Ukraine from Europe in 19th century. Possible origin of Ukrainian PVM isolates from India can be explained by the fact that India is one of the leading countries in potato growing in the world, from where it is transported abroad, including Ukraine. It should be noted that the some of Indian PVM isolates induced the abaxial leaf rolling symptoms on potato plants (Katiyar et al., 2013) similar to those we have identified in tomatoes in Ukraine.

Question about the determining factors in the phylogenetic divergence of PVM isolates into two main clades is still open. We did not reveal clear division of PVM strains and isolates according to the host plant. Moreover, the highest percentage of identity of Ukrainian tomato isolates was found 


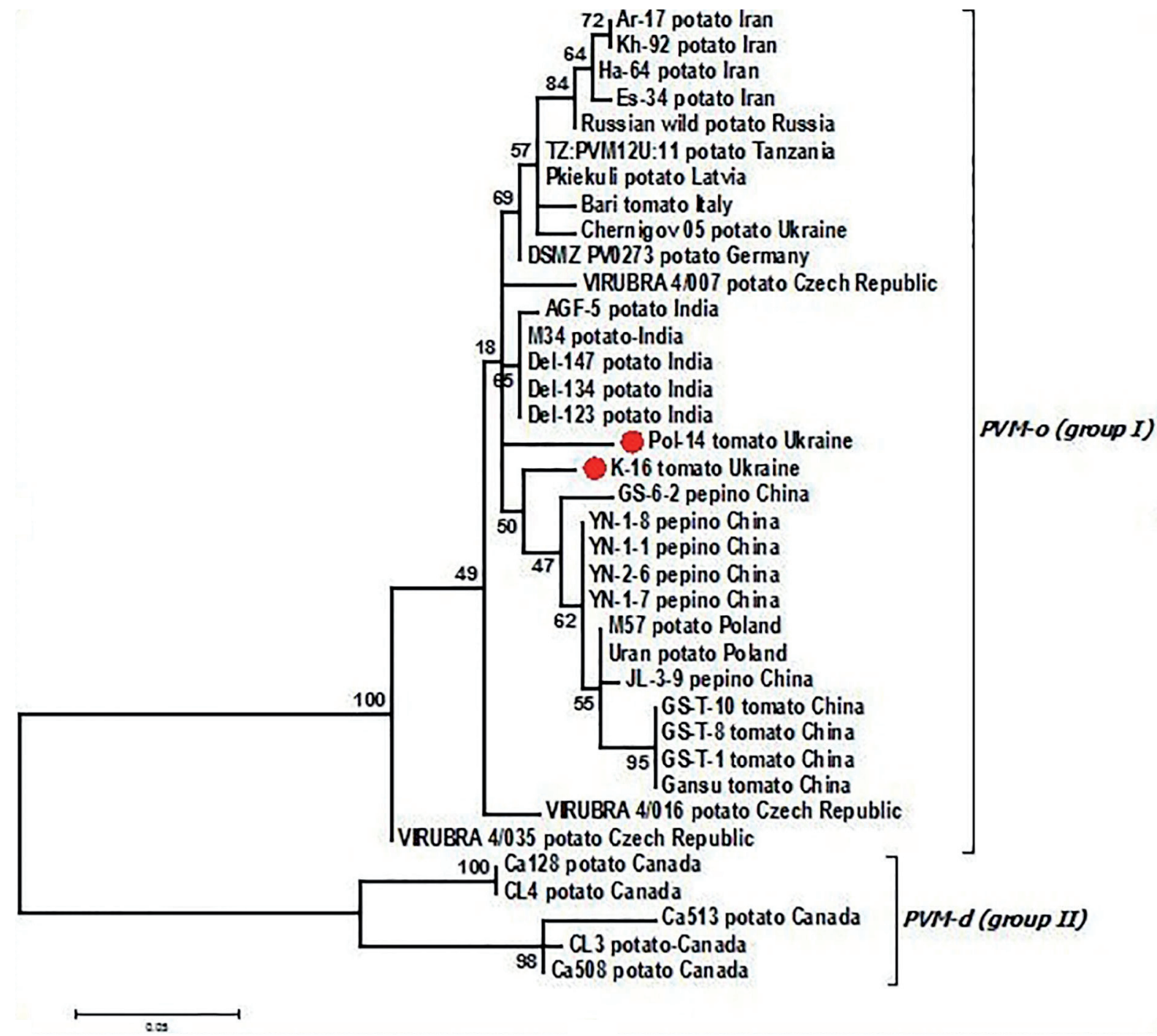

Fig. 2

Maximum likelihood (ML) tree based on nucleotide sequences of part of the CP gene of Ukrainian PVM isolates K-16 and Pol-14 and isolates from other countries (names and GenBank Acc. Nos. are given in Table 1)

The phylogenetic tree was constructed applying General Time Reversible (GTR) model. The values at the nodes indicate the percentage of replicate trees, in which associated taxa clustered together (number of bootstrap trails: 1000 replicates). The scale bar shows the number of substitutions per base.

with potato PVM strains. But on the other hand, analysis showed that isolates K-16 and Pol-14 have a high level of homology with tomato and pepino isolates (Table 1). Also, as seen from ML tree, all tomato and pepino isolates are located near each other, indicating their common origin (Fig. 2).

It was found that the nucleotide substitutions in the capsid protein gene of all tomato PVM isolates taken to this analysis (including those Ukrainian) are synonymous, i.e. those that do not lead to the amino acid substitution in the encoded protein. The exception is the Italian tomato isolate Bari, which has substitution of threonine to proline at position 250 .
To explore the evolutionary forces acting on the PVM CP gene, the $\mathrm{dN} / \mathrm{dS}$ values were calculated for all of the PVM $\mathrm{CP}$ sequences included in our study (Table 1). This ratio indicates the amount of nonsynonymous to synonymous mutations. $\mathrm{dN} / \mathrm{dS}$ ratio for isolate $\mathrm{K}-16$ compared to all other isolates was 0,033 , for isolate Pol-14-0,029. This indicates more synonymous nucleotide substitutions in CP gene of isolate Pol-14 compared to isolate K-16.

The global $\mathrm{dN} / \mathrm{dS}$ ratio for all of the sequences taken to the study was $0.041(\mathrm{p}<0,01)$. This value is less than 1 , showing that the PVM CP gene experiences a negative (purifying) 
selection pressure. Pairwise comparisons showed that the $\mathrm{dN} / \mathrm{dS}$ values were also significantly less than 1 for all of the $\mathrm{CP}$ sequence pairs. No CP sequence pair with significant positive selection $(\mathrm{dN} / \mathrm{dS}>1)$ was found in the pairwise comparisons. The same results were obtained for complete CP gene sequences (Tabasinejad et al., 2014). Thus, we suggest that genetic stability of PVM population is ensured by the effect of negative selection - selection to maintain the sustainability of the genome. Investigation of other PVM genes is necessary for more accurate conclusions and better understanding of PVM evolution.

Acknowledgments. The authors are grateful to colleagues from the Danylo Zabolotny Institute of Microbiology and Virology of National Academy of Science of Ukraine for help with electron microscope investigations.

\section{References}

Acosta-Leal R, Duffy S, Xiong Z, Hammond RW, Elena SF (2011): Advances in plant virus evolution: Translating evolutionary insights into better disease management. Phytopathology 101, 1136-1148. https://doi.org/10.1094/ PHYTO-01-11-0017

Adams MJ, Antoniw JF (2004): The new plant virus family Flexiviridae and assessment of molecular criteria for species demarcation. Arch. Virol. 149, 1045-1060. https://doi. org/10.1007/s00705-004-0384-x

Adams MJ, Candresse T, Hammond J, Kreuze JF, Martelli GP, Namba S, Pearson MN, Ryu KH, Saldarelli P, Yoshikawa N. (2012): Family Betaflexiviridae. In King AMQ, Adams MJ, Carstens EB, Lefkowitz EJ (Eds): Virus Taxonomy: Ninth Report of the International Committee on Taxonomy of Viruses. San Diego, CA, Elsevier-Academic Press, pp. 920-941.

Antipov IO, Spyrydonov VG, Melnychuk MD (2007): Phylogenetic analysis ofcapsid protein genes of Ukrainian potato viruses isolates. Scientific Bulletin of the Uzhgorod University. Series «Biology» 20, 220-225 (in Ukrainian).

Cox BA, Jones RAC (2010): Genetic variability in the coat protein gene of Potato virus $S$ isolates and distinguishing its biologically distinct strains. Arch. Virol. 155, 1163-1169. https://doi.org/10.1007/s00705-010-0680-6

Crowther JR (1995): ELISA. Theory and Practice. Hamana Press, N.Y., p. 223. https://doi.org/10.1385/0896032795

Chiunga E, Valkonen JPT (2013): First report of five viruses infecting potatoes in Tanzania. Plant Dis. 97, 1260. https://doi. org/10.1094/PDIS-02-13-0143-PDN

Flatken S, Ungewickell V, Menzel W, Maiss E (2008): Construction of an infectious full-length cDNA clone of Potato virus M. Arch. Virol. 153, 1385-1389. https://doi.org/10.1007/ $\underline{\text { s00705-008-0127-5 }}$
Garcia-Arenal F, Fraile A, Malpica JM (2003): Variation and evolution of plant virus populations. Int. Microbiol. 6, 225-232. https://doi.org/10.1007/s10123-003-0142-Z

Ge BB, He Z, Jiang DM, Zhang ZX, Liu GJ, Wang HQ (2012): Characterization and complete nucleotide sequence of Potato virus $\mathrm{M}$ isolated from tomato in China. Acta Virol. 56, 261-263. https://doi.org/10.4149/av 201203261

Grieco F, di Franco A, Gallitelli D (1997): Potato virus M in tomato crops in southern Italy. J. Plant Pathol. 79, 45-49. http:// www.ebi.ac.uk/Tools/msa/clustalw2/http://www.hiv.lanl. gov/content/sequence/SNAP/SNAP.html http://www. megasoftware.net/

Huelsenbeck JP, Rannala B (1997): Maximum likelihood estimation of phylogeny using stratigraphic data. Paleobiology 23, 174-180. https://doi.org/10.1017/S0094837300016778

Katiyar A, Kumar A, Mandal B (2013): Characterization of Potato virus $\mathrm{M}$ from India based on coat protein gene sequence. International conference (Asia Pacific Congress of Virology) of Indian Virological Society. Noida. https://www. researchgate.net/publication/269993570_Characterization_of_Potato_virus_M_from_India_based_on_coat_ protein_gene_sequence

Lauring AS, Frydman J, Andino R (2013): The role of mutational robustness in RNA virus evolution. Box 1: Mutation rates of RNA viruses and quasispecies theory. Nat. Rev. Microbiol. 11, 327-336. https://doi.org/10.1038/nrmicro3003

Mahy BWJ, Van Regenmortel MHV (2010): Desk Encyclopedia of Plant and Fungal Virology. Elsevier/Academic Press, Boston, p. 613.

Mishchenko LT, Dunich AA, Danilova OI, Polischuk VP (2013): Properties of Potato virus $\mathrm{M}$ and Potato virus Y tomato isolates in Ukraine. Mikrobiol. Zhurnal 75, 89-97.

Plchova H, Vaculik P, Cerovska N, Moravec T, Dedic P (2015): Molecular and biological analysis of Potato virus $\mathrm{M}$ (PVM) isolates from the Czech Republic. J. Plant Pathol. 1031-1035.

Pourrahim R, Farzadfar Sh, Golnaraghi AR, Ahoonmanesh A (2007): Incidence and distribution of important viral pathogens in some Iranian potato fields. Plant Dis. 91, 609-615. https://doi.org/10.1094/PDIS-91-5-0609

Salari K, Massumi H, Heydarnejad J, Hosseini Pour A, Varsani A (2011): Analysis of Iranian Potato virus $S$ isolates. Virus Genes 43, 281-288. https://doi.org/10.1007/s11262-011 -0619-3

Tabasinejad F, Jafarpour B, Zakiaghl M, Siampour M, Rouhani H, Mehrvar M (2014): Genetic structure and molecular variability of potato virus M populations. Arch. Virol. 159, 2081-2090. https://doi.org/10.1007/s00705-014-2037-z

Xu H, D'Aubin J, Nie J (2010): Genomic variability in Potato virus $\mathrm{M}$ and the development of RT-PCR and RFLP procedures for the detection of this virus in seed potatoes. Virol. J. 7, 25. https://doi.org/10.1186/1743-422X-7-25

Zavriev SK, Kanyuka KV, Levay KE (1991): The genome organization of Potato virus M RNA. J. Gen. Virol. 72, 9-14. https://doi.org/10.1099/0022-1317-72-1-9 